\title{
The influence of genetic background on the induction of oxidative stress and impaired insulin secretion in mouse islets
}

Received: 4 October 2005 / Accepted: 23 December 2005 / Published online: 29 March 2006

C) Springer-Verlag 2006

\begin{abstract}
Aims/hypothesis: We determined whether highglucose-induced beta cell dysfunction is associated with oxidative stress in the DBA/2 mouse, a mouse strain susceptible to islet failure. Materials and methods: Glucoseand non-glucose-mediated insulin secretion from the islets of DBA $/ 2$ and control C57BL/6 mice was determined following a 48-h exposure to high glucose. Flux via the hexosamine biosynthesis pathway was assessed by determining $O$-glycosylated protein levels. Oxidative stress was determined by measuring hydrogen peroxide levels and the expression of anti-oxidant enzymes. Results: Exposure to high glucose levels impaired glucose-stimulated insulin secretion in $\mathrm{DBA} / 2$ islets but not $\mathrm{C} 57 \mathrm{BL} / 6$ islets, and this was associated with reduced islet insulin content and lower ATP levels than in C57BL/6 islets. Exposure of islets to glucosamine for $48 \mathrm{~h} \mathrm{mim}$ icked the effects of high glucose on insulin secretion in the DBA $/ 2$ islets. High glucose exposure elevated $O$-glycosylated proteins; however, this occurred in islets from both strains, excluding a role for $O$-glycosylation in the impairment of DBA/2 insulin secretion. Additionally, both glucosamine and high glucose caused an increase in hydrogen peroxide in DBA/2 islets but not in C57BL/6 islets, an effect prevented by the antioxidant $\mathrm{N}$-acetylL-cysteine. Interestingly, while glutathione peroxidase and catalase expression was comparable between the two strains, the antioxidant enzyme manganese superoxide dismutase, which converts superoxide to hydrogen peroxide, was increased in $\mathrm{DBA} / 2$ islets, possibly explaining the increase in hydrogen peroxide levels.
\end{abstract}

\footnotetext{
S. Zraika $\cdot$ K. Aston-Mourney $\cdot$ M. Kebede $\cdot$ M. E. Dunlop ·

J. Proietto $\cdot$ S. Andrikopoulos $(\bowtie)$

Department of Medicine (AH/NH), University of Melbourne,

Heidelberg Repatriation Hospital,

Heidelberg Heights, VIC 3081, Australia

e-mail: sof@unimelb.edu.au

Tel.: +61-3-94962403

Fax: +61-3-94974554

D. R. Laybutt

Garvan Institute of Medical Research,

Sydney, NSW, Australia
}

Conclusions/interpretation: Chronic high glucose culture caused an impairment in glucose-stimulated insulin secretion in $\mathrm{DBA} / 2$ islets, which have a genetic predisposition to failure, and this may be the result of oxidative stress.

Keywords Anti-oxidants · Glucosamine · Glucose-stimulated insulin secretion - Glucose toxicity . Hexosamine biosynthesis pathway - Oxidative stress

Abbreviations GFAT: glutamine:fructose-6-phosphate amidotransferase-1 · GSIS: glucose stimulated insulin secretion - HBP: hexosamine biosynthesis pathway $\cdot \mathrm{H}_{2} \mathrm{O}_{2}$ : hydrogen peroxide $\cdot$ Mn-SOD: manganese superoxide dismutase $\cdot \mathrm{NAC}: \mathrm{N}$-acetylcysteine

\section{Introduction}

Two fundamental defects arise in the progression from normal glucose tolerance to type 2 diabetes: a decrease in the ability of tissues to respond to insulin and an inability of beta cells to produce enough insulin to compensate for the insulin-resistant state. Chronic elevations in blood glucose have been shown to induce a number of defects in the islet beta cell. Notably, the term 'glucotoxicity' originated following studies demonstrating the impaired glucose stimulatory effect on insulin secretion following high glucose exposure [1-3]. Despite intense research in this field, the mechanism for the decline in insulin output remains incompletely understood.

A number of studies have implicated 'beta cell exhaustion' as the cause of impaired insulin secretory function [4-6], as well as a reduction in insulin gene transcription factors $[7,8]$, and glucokinase protein and activity levels $[9,10]$. Furthermore, recent evidence suggests that changes in the early steps of insulin receptor signalling may also play a role in hyperglycaemia-induced beta cell dysfunction [11].

One mechanism for hyperglycaemia-induced damage is via the generation of superoxide radicals, which result in oxidative stress [12]. The defence mechanism against this 
oxidative stress are antioxidant enzymes like superoxide dismutase and catalase, which convert the superoxide into harmless products. Interestingly, the pancreatic beta cell is particularly sensitive to oxidative stress because of the presence of low levels of antioxidant enzymes [13], thus it can be perceived that hyperglycaemia may cause dysfunction of beta cells via oxidative stress [14]. In fact, this phenomenon has been investigated extensively (reviewed in [15]) and possibly provides the most convincing rationale to explain the reduced secretory capacity of the beta cell following chronic glucose exposure. In support of this, a recent study showed impaired function associated with increased oxidative stress in islets isolated from patients with type 2 diabetes, which was improved when the islets were treated with the anti-oxidant glutathione [16]. On the other hand, what remains in question is how glucose overload generates superoxide. Potential pathways that have been suggested for superoxide production include glycosylation (Schiff reaction) [17], glucose autoxidation [18], glucose metabolism [19,20] and the hexosamine biosynthesis pathway (HBP) [21]. We have previously shown that regulation of flux through the HBP can concomitantly regulate the secretion of insulin from mouse islets [22].

In the present study, the contribution of the HBP to high glucose-induced changes in islets was investigated in two mouse models with different susceptibility to beta cell failure, the C57BL/6 control strain and the DBA/2 susceptible strain $[23,24]$. We show that in response to 2 days of culture in high glucose, only the DBA/2 islets display a reduced insulin response to a glucose stimulus, as well as increased levels of hydrogen peroxide; this suggests the involvement of oxidative stress. These effects are mimicked by incubation with the HBP substrate glucosamine and are reversed following incubation with the antioxidant agent $N$-acetyl-L-cysteine. Therefore, these results suggest a role for high glucose-induced oxidative stress and impaired secretory function, only in genetically predisposed islets.

\section{Materials and methods}

Isolation and culture of pancreatic islets

We have previously shown that insulin sensitivity and levels of fasting plasma glucose and insulin were similar in DBA/2 and C57BL/6 mice [25]. Islets were isolated from the pancreas of 7- to 8-week-old male C57BL/6 and DBA/2 mice (Walter and Eliza Hall Institute Animal Research Facility; Kew, VIC, Australia) by collagenase digestion as previously described [22]. Briefly, pancreata were digested by intraductal injection of Collagenase $\mathrm{P}(0.5 \mathrm{mg} / \mathrm{ml})$ in RPMI-1640 (with L-glutamine) containing $100 \mathrm{U} / \mathrm{ml}$ penicillin, $100 \mu \mathrm{g} / \mathrm{ml}$ streptomycin and $11.1 \mathrm{mmol} / 1$ glucose. Islets were purified using a Histopaque-1077 density gradient. After the islets were freed from the exocrine tissue, they were hand-picked under a stereomicroscope (Olympus, Tokyo, Japan) and transferred for overnight culture in RPMI-1640 medium with $10 \%$ (vol $/ \mathrm{vol}$ ) heat-inactivated fetal calf serum, in a $37^{\circ} \mathrm{C}$ humidified atmosphere of $95 \%$ air: $5 \% \mathrm{CO}_{2}$. All the animal procedures were approved by the Animal Ethics Committee of Austin Health Victoria.

\section{Evaluation of insulin secretion and content}

A supraphysiological concentration of glucose $(40 \mathrm{mmol} / \mathrm{l})$ was used to culture islets so that a functional defect could be induced in the relatively short incubation period of $48 \mathrm{~h}$. Following overnight culture, batches of islets were transferred to Petri dishes containing RPMI-1640 (with either 11.1 or $40 \mathrm{mmol} / \mathrm{l}$ glucose) in the absence or presence of $3 \mathrm{mmol} / \mathrm{l}$ glucosamine or $\mathrm{N}$-acetylglucosamine and/or $5 \mathrm{mmol} / \mathrm{l} \mathrm{N}$-acetyl-L-cysteine. Islets were cultured at $37^{\circ} \mathrm{C}$ for $48 \mathrm{~h}$ then preincubated for $90 \mathrm{~min}$ in KrebsRinger bicarbonate buffer (KRBB) with $2.8 \mathrm{mmol} / \mathrm{l}$ glucose. Triplicate batches of five islets each were then transferred to tubes containing $1 \mathrm{ml}$ KRBB supplemented with either 2.8 or $20 \mathrm{mmol} / 1$ glucose. Additional stimulation with a cocktail of secretagogues was carried out in some experiments: $0.5 \mathrm{~m} \mathrm{KRBB}$ was replaced with a secretagogue cocktail containing $0.1 \mathrm{mmol} / 13$-isobutyl1-methylxanthine, $10 \mathrm{mmol} / \mathrm{l}$ arginine and $5 \mu \mathrm{mol} / \mathrm{l}$ carbamylcholine chloride (carbachol).

After a 60 -min incubation of the islets at $37^{\circ} \mathrm{C}$, the tubes were centrifuged at $500 \times g$ for $5 \mathrm{~min}$ and $0.5 \mathrm{ml}$ supernatant was removed for insulin analysis. The remaining $0.5 \mathrm{ml}$ containing the islets was treated with $0.18 \mathrm{~mol} / \mathrm{l}$ $\mathrm{HCl} / 95 \%$ ethanol, followed by sonication to determine the insulin content.

Insulin levels were determined with a double antibody radioimmunoassay using a rat-specific insulin antibody and rat insulin as a standard (Linco Research; St Charles, MO, USA).

\section{Measurement of islet ATP}

ATP was measured as previously described [26] using an ATP assay kit from Sigma (St Louis, MO, USA); $50 \mu \mathrm{l}$ of each sample or ATP standard was mixed with an equal amount of ATP assay mix, containing luciferase, luciferin, $\mathrm{MgSO}_{4}$, dithiothreitol, EDTA, BSA and tricine buffer salts. The light emitted was measured in a luminometer and is proportional to the ATP present.

\section{Assessment of ${ }^{51} \mathrm{Cr}$ release}

Release of ${ }^{51} \mathrm{Cr}$ was used to assess cell viability following exposure to high glucose levels, as previously described [27]. Data were expressed as percentage of ${ }^{51} \mathrm{Cr}$ release in terms of total incorporation (cpm in medium $/[\mathrm{cpm}$ in medium + cpm in islets]). 
Western blotting analysis of islet glycosylated proteins

Following incubations with test compounds, Western blotting was carried out as previously described [22], with the monoclonal mouse anti-O-linked $\mathrm{N}$-acetylglucosamine antibody (RL2; Affinity Bioreagents, Golden, CO, USA).

\section{Hydrogen peroxide assay}

Hydrogen peroxide levels were determined as previously described [21], using the PeroxiDetect kit (Sigma). Briefly, $20 \mu \mathrm{l}$ of islet lysate was incubated with aqueous peroxide colour reagent (aqueous solution containing $100 \mathrm{mmol} / \mathrm{l}$ sorbitol and $125 \mu \mathrm{mol} / \mathrm{l}$ xylenol orange) and ferrous ammonium sulphate reagent $(25 \mathrm{mmol} / \mathrm{l}$ ferrous ammonium sulphate in $2.5 \mathrm{~mol} / 1$ sulphuric acid) for at least $30 \mathrm{~min}$. The $\mathrm{H}_{2} \mathrm{O}_{2}$ levels were measured in a microtitre plate reader (BioRad Model 680 microplate reader; Bio-Rad, Hercules, CA, USA) by the absorbance at $595 \mathrm{~nm}$. The $\mathrm{H}_{2} \mathrm{O}_{2}$ levels in the lysates were calculated from the standard curve of nanomole $\mathrm{H}_{2} \mathrm{O}_{2}$ against optical density at $595 \mathrm{~nm}$.

\section{Real-time PCR}

Total RNA was prepared as previously described [28] from islets incubated with $11.1 \mathrm{mmol} / \mathrm{l}$ glucose (before high glucose exposure) and $1 \mu \mathrm{g}$ per reaction was converted to cDNA using the Promega Reverse Transcriptase System kit (Promega Corporation, Madison, WI, USA) according to the manufacturer's instructions. Real-time PCR was carried out in a volume of $10 \mu \mathrm{l}$ consisting of $1 \mu \mathrm{l}$ cDNA, $1 \times$ LightCycler enzyme and reaction mix (SYBR Green I dye, Taq DNA polymerase, dNTP; Roche Diagnostics Australia, Castle Hill, NSW, Australia), $1.5 \mathrm{mmol} / 1 \mathrm{MgCl}_{2}$ and $600 \mathrm{nmol}$ of oligonucleotide primers (Proligo Australia, Lismore, NSW, Australia). The oligonucleotide primers were designed with MacVector software (Oxford Molecular, Oxford, UK). All reactions were performed in a LightCycler (Roche), in which samples underwent 40 cycles of PCR with an annealing temperature of $55^{\circ} \mathrm{C}$. Standards for each transcript were prepared in a conventional PCR and purified using a High Pure PCR Product Purification Kit (Roche). The following primers were used (forward and reverse): ATGAAGCAGTGGAAGGAGCAGC and CTGTCAAAG TGTGCCATCTCGTC (catalase), ACAGTCCACCGTGTA TGCCTTC and CTCTTCATTCTTGCCATTCTCCTG (glutathione peroxidase), CCACACAGCACTATGTAA AGCGTC and GTTCGGGAAGGTAAAAAAAGCC (haeme oxygenase-1), ATGGGGACAATACACAAGGC TG and CAATGATGGAATGCTCTCCTGAG (Cu/Znsuperoxide dismutase [SOD]), GGGAGATGTTACAACT CAGGTC GC and CCAAAGTCACGCTTGATAGCCTC (Mn-SOD), TCTTCTACACACCCATGTCCC and GGT GCAGCACTGATCTAC (insulin), and TGTGCCAGGG TGGTGACTTTAC and TGGGAACCGTTTGTGTTT GG (cyclophilin). The value obtained for each specific product was expressed relative to the control gene for each sample (ratio of specific product to cyclophilin). These ratios were then expressed as a percentage of the ratio in C57BL/6 islet extracts.

Western blotting and activity assays of anti-oxidant enzymes

The Mn-SOD protein levels were measured in mitochondrial lysates [29] from islets and various tissues both in the normal state and before high glucose exposure using Western blotting and employing a specific polyclonal antibody (cat. no. sc-18503 Santa Cruz Biotechnology, Santa Cruz, CA, USA). Islet catalase and glutathione peroxidase enzyme activity was determined using commercially available kits and following the manufacturer's directions (Cayman Chemical, Ann Arbor, MI, USA). All Western blotting and enzyme activity assays were corrected for the amount of protein in the sample using the Bio-Rad protein assay kit (Bio-Rad).

Statistical analysis

Data are presented as the mean \pm standard error of the mean (SEM) for the number of experiments indicated. Statistical significance was determined using the two-tailed Student's $t$-test for non-parametric data. A $p$ value $<0.05$ was considered statistically significant.

\section{Results}

Incubation of DBA/2 mouse islets with $11.1 \mathrm{mmol} / 1$ glucose for $48 \mathrm{~h}$ resulted in a marked increase in glucosestimulated insulin secretion (GSIS) compared with C57BL/6 islets. We have previously demonstrated this enhanced insulin response in the DBA/2 mouse [30] and found it to be a consequence of increased glucose utilisation. Incubation in $40 \mathrm{mmol} / 1$ glucose significantly reduced GSIS from DBA/2 islets, but not from C57BL/6 islets (Fig. 1a). The increase in insulin release (from 2.8 to $20 \mathrm{mmol} / 1$ glucose) was ninefold following culture with $11.1 \mathrm{mmol} / 1$ glucose but only fourfold following culture with $40 \mathrm{mmol} / \mathrm{l}$ glucose for DBA/2 islets. In comparison, in C57BL/6 islets there were fourfold and threefold increases in insulin secretion following culture with 11.1 and $40 \mathrm{mmol} / 1$ glucose, respectively. Insulin secretion in response to $20 \mathrm{mmol} / \mathrm{l}$ glucose plus a cocktail of secretagogues was unaffected by $40 \mathrm{mmol} / \mathrm{l}$ glucose incubation in both strains (Fig. 1b), indicating that the reduction in insulin release in DBA/2 islets was specific to glucose.

To exclude other possible reasons for the reduction in DBA/2 insulin secretion caused by high glucose, ATP levels and cell viability $\left({ }^{51} \mathrm{Cr}\right.$-release assay) were analysed in islets incubated in either 11.1 or $40 \mathrm{mmol} / 1$ glucose. Table 1 shows that in both strains, basal ATP levels for 


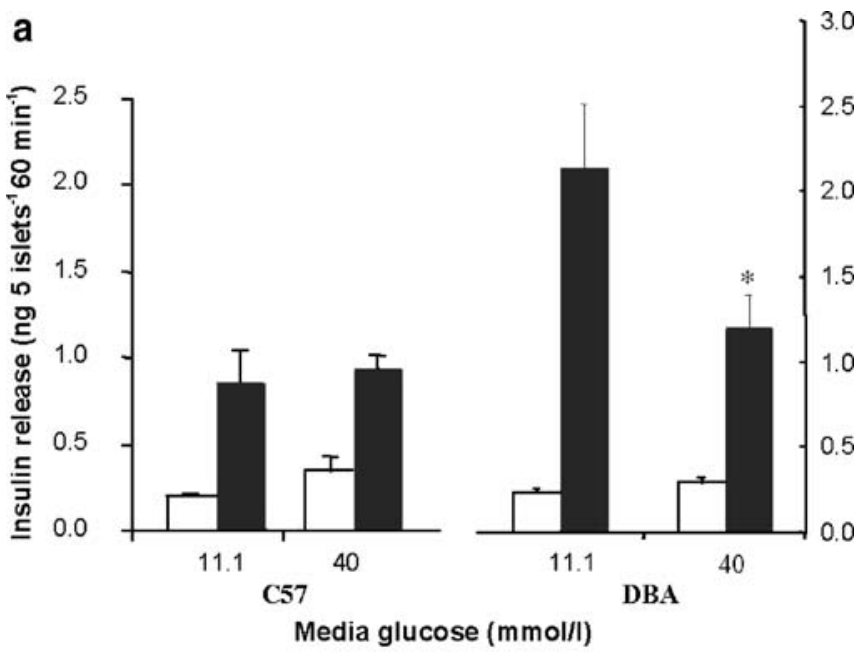

b

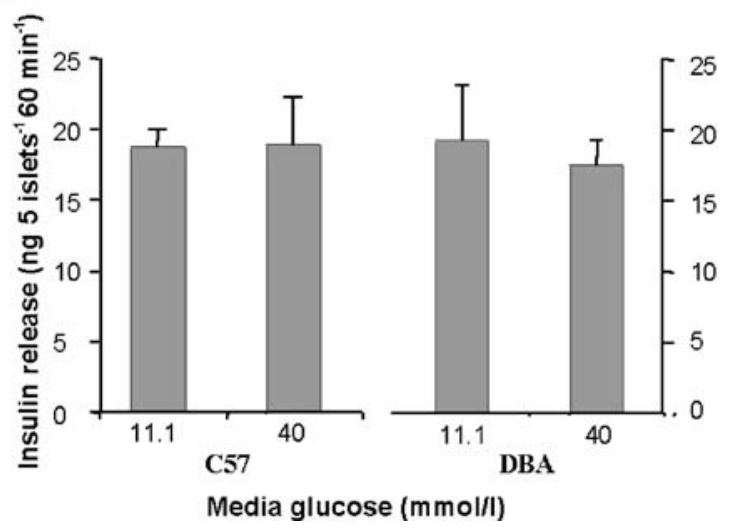

Fig. 1 Insulin secretion following $48 \mathrm{~h}$ incubation in either 11.1 or $40 \mathrm{mmol} / \mathrm{l}$ glucose. Islets were preincubated in KRBB with $2.8 \mathrm{mmol} / 1$ glucose for $90 \mathrm{~min}$ and then stimulated for $60 \mathrm{~min}$ with either 2.8 (open bars) or $20 \mathrm{mmol} / 1$ glucose (closed bars) (a) and $20 \mathrm{mmol} / 1$ glucose plus secretagogue cocktail (shaded bars) containing $10 \mathrm{mmol} / 1$ arginine, $0.1 \mathrm{mmol} / 1 \mathrm{IBMX}$ and $5 \mu \mathrm{mol} / 1$ carbachol (b). Values are presented as mean \pm SEM for five to 13 experiments. ${ }^{*} p<0.05$ vs $11.1 \mathrm{mmol} / 1$

islets that had been incubated in $40 \mathrm{mmol} / \mathrm{l}$ glucose tended to increase compared with those incubated in $11.1 \mathrm{mmol} / 1$ glucose. However, when stimulated, the DBA/2 islets incubated in $40 \mathrm{mmol} / \mathrm{l}$ glucose had significantly lower ATP levels that those incubated in $11.1 \mathrm{mmol} / 1$ glucose. This effect was not seen in C57BL/6 islets. Furthermore, the increase in ATP levels (from 2.8 to $20 \mathrm{mmol} / \mathrm{l}$ glucose) was 13.6 -fold following culture in $11.1 \mathrm{mmol} / 1$ glucose and this increase was considerably less, only 1.7 -fold, following $40 \mathrm{mmol} / 1$ glucose culture for DBA/2 islets while in $\mathrm{C} 57 \mathrm{BL} / 6$ islets the increases in insulin secretion were 2.2-fold and 1.2-fold following 11.1 and $40 \mathrm{mmol} / 1$ glucose culture, respectively. ${ }^{51} \mathrm{Cr}$ release (Table 1) was increased in both strains following high glucose exposure, with the levels released from $\mathrm{DBA} / 2$ islets being significantly higher than from $\mathrm{C} 57 \mathrm{BL} / 6$ islets. Even so, this percentage release $(3.45 \pm 0.09 \%)$ was relatively low and cannot completely explain the impairment in GSIS from the $\mathrm{DBA} / 2$ islets.

To investigate the involvement of the HBP on beta cell function in the mouse islets, we studied the effects of its specific substrate glucosamine on insulin secretion. Figure 2 shows that glucosamine mimicked the impairment in GSIS seen in DBA/2 islets following $40 \mathrm{mmol} / 1$ glucose incubation, suggesting a role for the HBP in high-glucoseinduced beta cell dysfunction. Furthermore, $48 \mathrm{~h}$ glucosamine in the presence of $11.1 \mathrm{mmol} / 1$ glucose treatment also suppressed GSIS from C57BL/6 islets.

Previously, we have shown that under normal conditions, inhibition of the HBP was associated with modification of insulin secretion by modulating islet protein $O$-glycosylation [22]. That is, when the glutamine:fructose6-phosphate amidotransferase-1 (GFAT) inhibitor azaserine was used to reduce flux through the HBP and therefore decrease protein $O$-glycosylation, insulin secretion was also reduced. Thus here, we determined whether increased HBP flux, as determined by the level of islet protein $O$-glycosylation, could also be associated with defective insulin secretion. Both $\mathrm{C} 57 \mathrm{BL} / 6$ and $\mathrm{DBA} / 2$ islets incubated with $40 \mathrm{mmol} / \mathrm{l}$ glucose showed an increased level of protein $O$-glycosylation compared with those incubated with $11.1 \mathrm{mmol} / \mathrm{l}$ glucose. A representative immunoblot is shown in Fig. 3. This increase was most apparent in the band indicated by the arrow, which has been identified as $\mathrm{O}-\mathrm{N}$-acetylglucosamine transferase [31], the enzyme responsible for the addition of $\mathrm{N}$-acetylglucosamine to proteins. Similarly, in both strains of mice co-incubation of $11.1 \mathrm{mmol} / \mathrm{l}$ glucose-treated islets with $\mathrm{N}$-acetylglucosamine (another substrate for the HBP) also resulted in an increase in $O$-glycosylation compared with incubation in $11.1 \mathrm{mmol} / \mathrm{l}$ glucose alone. Therefore the increase in protein $O$-glycosylation following high glucose

Table 1 The effect of 48-h exposure to either 11.1 or $40 \mathrm{mmol} / 1$ glucose on ATP levels $(n=4)$ and cell viability $(n=3)$ in C57BL/6 and $\mathrm{DBA} / 2$ mouse islets

$\mathrm{C} 57 \mathrm{BL} / 6 \quad \mathrm{DBA} / 2$

$\begin{array}{llll}11.1 \mathrm{mmol} / 1 & 40 \mathrm{mmol} / \mathrm{l} & & 11.1 \mathrm{mmol} / \mathrm{l}\end{array}$

ATP (pmol/islet)

Basal $(2.8 \mathrm{mmol} / 1$ glucose $)$

$1.12 \pm 0.28$

$2.52 \pm 0.83$

2.2

Fold increase (from $2.8 \mathrm{mmol} / \mathrm{l}$ )

Percentage of ${ }^{51} \mathrm{Cr}$ release
$1.76 \pm 0.14$

$1.23 \pm 0.35$
$16.30 \pm 1.66+$
13.6

$1.77 \pm 0.09$
$3.59 \pm 1.51$

$6.12 \pm 1.88^{*}$

1.7

$3.45 \pm 0.09 * \dot{\dagger}$

${ }^{*} p<0.05$ vs $11.1 \mathrm{mmol} / 1, \dagger p<0.05$ vs $\mathrm{C} 57 \mathrm{BL} / 6, \ddagger p<0.05$ vs basal 
Fig. 2 Insulin secretion following $48 \mathrm{~h}$ incubation in either 40 glucose or $11.1 \mathrm{mmol} / 1$ glucose in the absence or presence of $3 \mathrm{mmol} / 1$ glucosamine $(\mathrm{GlcN})$. Islets were preincubated in $\mathrm{KRBB}$ with $2.8 \mathrm{mmol} / \mathrm{l}$ glucose for $90 \mathrm{~min}$ and then stimulated for $60 \mathrm{~min}$ with either 2.8 (open bars) or $20 \mathrm{mmol} / 1$ (closed bars) glucose. Values are presented as mean $\pm \mathrm{SEM}$ for six experiments. ${ }^{*} p<0.05$ vs $11.1 \mathrm{mmol} / 1$

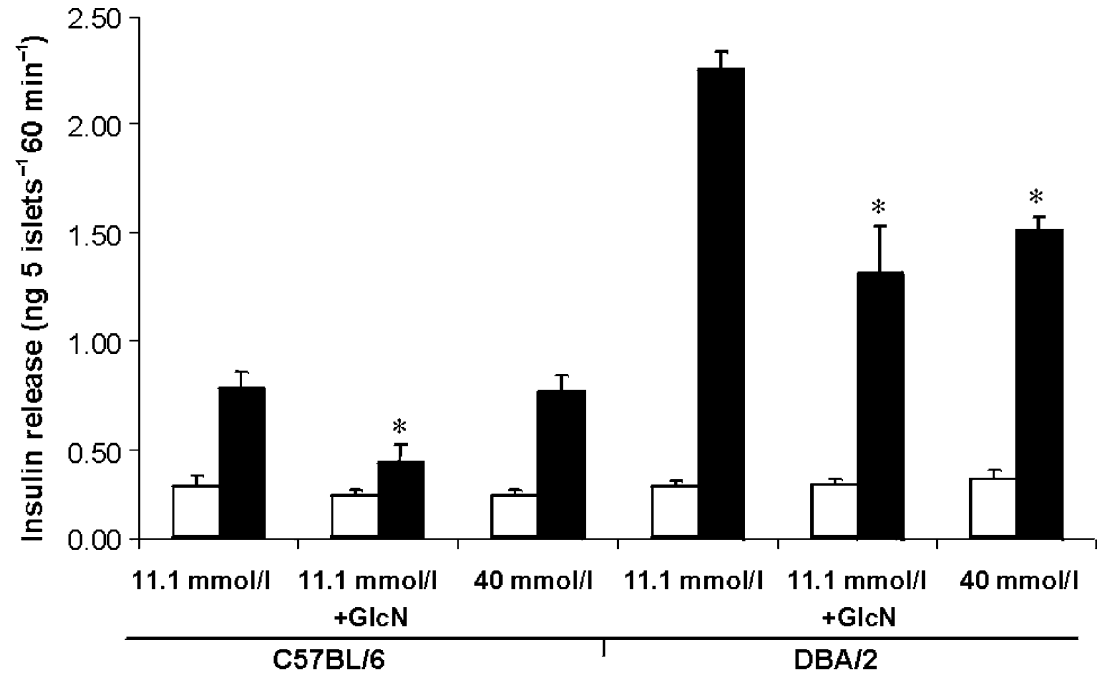

incubation was probably not the cause of reduced GSIS from $\mathrm{DBA} / 2$ islets under these conditions.

It has also been shown that a high glucose milieu may cause islet dysfunction via the generation of oxidative stress [12]. Thus an alternative hypothesis could be that $40 \mathrm{mmol} / \mathrm{l}$ glucose incubation would induce oxidative stress in the DBA/2 islets, which would then result in impaired GSIS. Hydrogen peroxide levels were measured as an indicator of oxidative stress and found to be elevated in DBA/2 islets incubated with 40 or $11.1 \mathrm{mmol} / 1$ glucose plus glucosamine (Fig. 4). Treatment with the antioxidant, $N$-acetyl-L-cysteine (NAC), reversed this increase in $\mathrm{H}_{2} \mathrm{O}_{2}$ and removed the GSIS defect in DBA/2 islets incubated

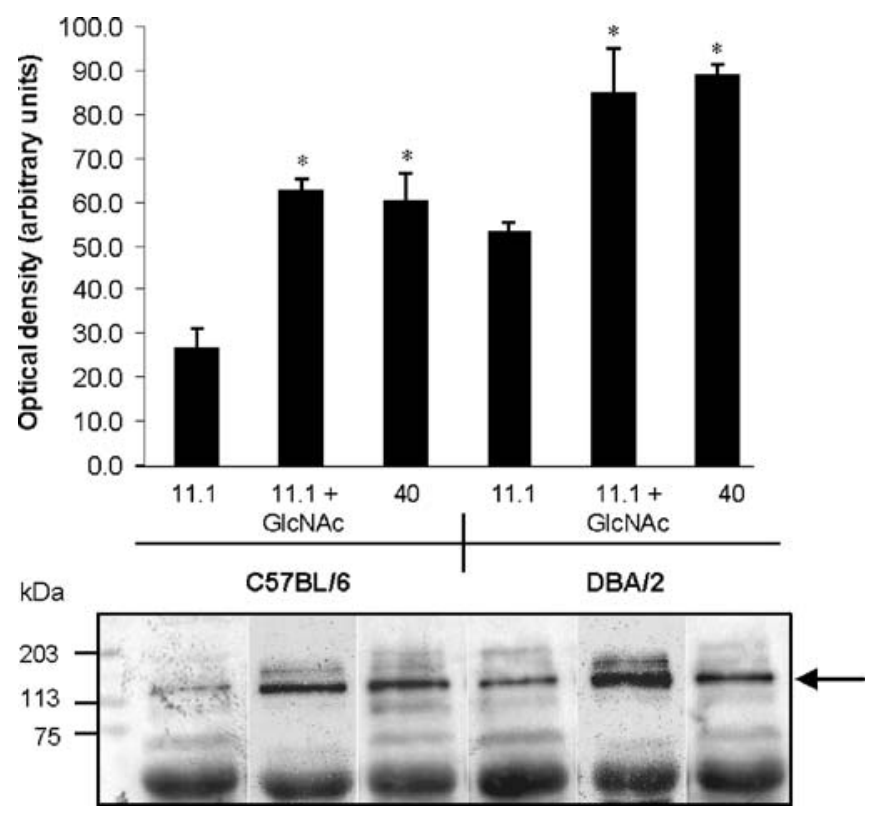

Fig. 3 Islet protein glycosylation following $48 \mathrm{~h}$ incubation in either 40 glucose or $11.1 \mathrm{mmol} / \mathrm{l}$ glucose in the absence or presence of $3 \mathrm{mmol} / 1 \mathrm{~N}$-acetylglucosamine $(G l c N A c)$. Western blotting was performed with the RL2 antibody for $O$-linked glycosylation. This immunoblot is a representative of three independent experiments. $* p<0.05$ vs $11.1 \mathrm{mmol} / 1$ with $40 \mathrm{mmol} / \mathrm{l}$ glucose but it had no effect on insulin release from C57BL/6 islets (Fig. 5).

To investigate whether the increase in oxidative stress (as indicated by higher $\mathrm{H}_{2} \mathrm{O}_{2}$ concentrations) was the result of altered levels of antioxidant enzymes in the DBA/2 strain compared with the C57BL/6 strain, real-time PCR was performed on cDNA prepared from islets before high glucose exposure. Surprisingly, expression of Mn-SOD was elevated and may thus have been responsible for the higher $\mathrm{H}_{2} \mathrm{O}_{2}$ levels in the DBA/2 islets, while haeme oxygenase- 1 , glutathione peroxidase, $\mathrm{Cu} / \mathrm{Zn}$-SOD and catalase were comparable between the two strains (Fig. 6). Furthermore, high glucose and glucosamine culture did not further increase Mn-SOD in DBA/2 islets ( $187 \pm 10$ vs $211 \pm 54$ vs $187 \pm 7,11.1$ vs $40 \mathrm{mmol} / 1$ glucose vs glucosamine, respectively, expressed as a percentage of C57BL/6 level). There was also no difference in islet insulin mRNA in the two strains of mice following $11.1 \mathrm{mmol} / \mathrm{l}$ glucose incubation.

An increase in Mn-SOD protein levels in $\mathrm{DBA} / 2$ compared with $\mathrm{C} 57 \mathrm{BL} / 6$ pancreata was also detected using Western blotting (Fig. 7a). Protein levels of Mn-SOD in liver and kidney tissue were comparable between these two strains while there was a modest $(25 \%)$ increase in heart tissue from DBA/2 mice compared with the $\mathrm{C} 57 \mathrm{BL} / 6$ mice (Fig. 7b). Islet activity levels of catalase (12.28 2 2.42 vs $11.04 \pm 1.54 \mathrm{nmol} \cdot \mathrm{min}^{-1} \cdot \mathrm{mg}^{-1}$ protein; $n=3$ or $n=4$, DBA/2 vs C57BL/6) and glutathione peroxidase $(0.0124 \pm$ 0.0029 vs $0.0137 \pm 0.0023 \mathrm{nmol} \cdot \mathrm{min}^{-1} \cdot \mathrm{mg}^{-1}$ protein, $n=4$, $\mathrm{DBA} / 2$ vs $\mathrm{C} 57 \mathrm{BL} / 6)$ were also comparable between $\mathrm{DBA} / 2$ and $\mathrm{C} 57 \mathrm{BL} / 6$ mice.

To investigate the effect of $40 \mathrm{mmol} / 1$ glucose on the levels of intracellular insulin, islet insulin content was measured. As shown in Fig. 8, DBA/2 islets incubated in $40 \mathrm{mmol} / \mathrm{l}$ glucose had less insulin content compared with islets incubated in $11.1 \mathrm{mmol} / 1$ glucose. Similarly, both $\mathrm{C} 57 \mathrm{BL} / 6$ and $\mathrm{DBA} / 2$ islets contained less insulin when incubated with $11.1 \mathrm{mmol} / 1$ glucose plus glucosamine, compared with $11.1 \mathrm{mmol} / 1$ glucose alone. NAC restored insulin content in DBA/2 islets to levels comparable with the $11.1 \mathrm{mmol} / \mathrm{l}$ glucose group. Since the secretagogue 
Fig. 4 Hydrogen peroxide levels in C57BL/6 (closed bars) and DBA/2 (open bars) islets following $48 \mathrm{~h}$ incubation in either $11.1 \mathrm{mmol} / 1$ glucose with or without $3 \mathrm{mmol} / \mathrm{l}$ glucosamine $(G l c N)$ or $40 \mathrm{mmol} / 1$ glucose with or without $5 \mathrm{mmol} /$ $1 \mathrm{~N}$-acetyl-L-cysteine $(N A C)$. Values are presented as mean \pm SEM for four to six experiments. ${ }^{*} p<0.05$ vs DBA/ 2 $11.1 \mathrm{mmol} / 1$ glucose, $\# p<0.05$ vs DBA/2 $40 \mathrm{mmol} / 1$ glucose

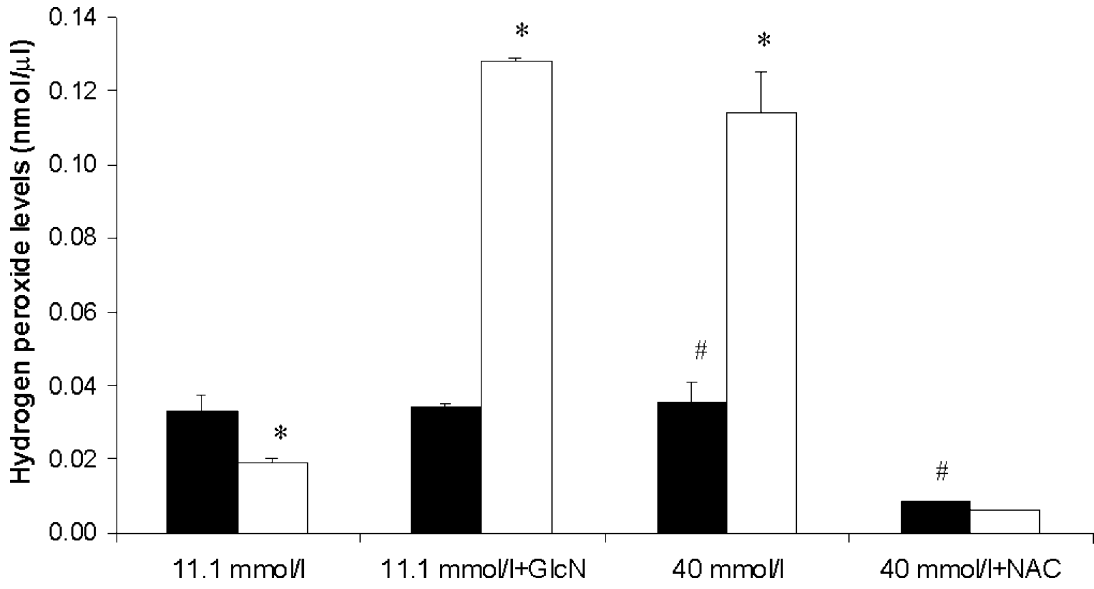

cocktail was able to evoke an insulin response greater than that of $20 \mathrm{mmol} / \mathrm{l}$ glucose alone and comparable with C57BL/6 islets (Fig. 1b), we believe that insulin content alone cannot be seen as the limiting factor for reduced GSIS in DBA/2 islets. Insulin accumulation in the media over the 48-h incubation period was collected and measured to ascertain whether or not beta cell exhaustion was taking place as a result of exposure to $40 \mathrm{mmol} / 1$ glucose. Both $\mathrm{C} 57 \mathrm{BL} / 6$ and $\mathrm{DBA} / 2$ islets secreted significantly more insulin over $48 \mathrm{~h}$ when incubated in $40 \mathrm{mmol} / \mathrm{l}$ glucose compared with $11.1 \mathrm{mmol} / 1$ glucose (DBA/2: $1.38 \pm 0.28 \mathrm{ng} \cdot$ islet $^{-1} \cdot 5 \mathrm{ml}^{-1}$ of $40 \mathrm{mmol} / 1 \mathrm{media}$ vs $0.33 \pm 0.06 \mathrm{ng}$ islet $^{-1} \cdot 5 \mathrm{ml}^{-1}$ of $11.1 \mathrm{mmol} / 1$ media; C57BL/6: $1.26 \pm 0.24 \mathrm{ng}_{\text {islet }}^{-1} \cdot 5 \mathrm{ml}^{-1}$ of $40 \mathrm{mmol} / 1 \mathrm{media}$ vs $0.16 \pm 0.02 \mathrm{ng} \operatorname{islet}^{-1} \cdot 5 \mathrm{ml}^{-1}$ of $11.1 \mathrm{mmol} / 1$ media; $n=4$, $p<0.0540 \mathrm{vs} 11.1 \mathrm{mmol} / \mathrm{l}$ for both strains). However, the levels in the $40 \mathrm{mmol} / \mathrm{l}$ glucose group were comparable between the two strains and therefore cannot explain the reduced insulin content in the DBA/ 2 islets. Thus, as previously suggested [8], it is likely that $40 \mathrm{mmol} / 1$ glucose suppresses insulin biosynthesis in these islets to some extent.

\section{Discussion}

The DBA/2 mouse strain displays susceptibility to pancreatic islet failure when stressed with insulin resistance or high glucose [32]. When the $d b / d b$ gene (which encodes for a defective leptin receptor molecule) is expressed on the DBA/2 background, mice are initially hyperinsulinaemic with normoglycaemia but soon develop overt hyperglycaemia as a result of decreased insulin production from a reduced beta cell population $[23,24]$. In contrast, $d b / d b$ gene expression on a C57BL/6 genetic background results in marked obesity and insulin resistance, with only mild hyperglycaemia and hyperinsulinaemia as a result of hypertrophy and hyperplasia of beta cells [33]. In the
Fig. 5 Glucose-stimulated insulin secretion following $48 \mathrm{~h}$ incubation in either 11.1 or $40 \mathrm{mmol} / 1$ glucose in the absence or presence of $5 \mathrm{mmol} / \mathrm{l}$ $\mathrm{N}$-acetyl-L-cysteine (NAC). Triplicate batches of five islets each were then transferred to tubes containing $1 \mathrm{ml} \mathrm{KRBB}$ supplemented with either 2.8 (open bars) or $20 \mathrm{mmol} / 1$ (closed bars) glucose. Values are presented as mean \pm SEM for four experiments. ${ }^{*} p<0.05$ vs $40 \mathrm{mmol} / 1$

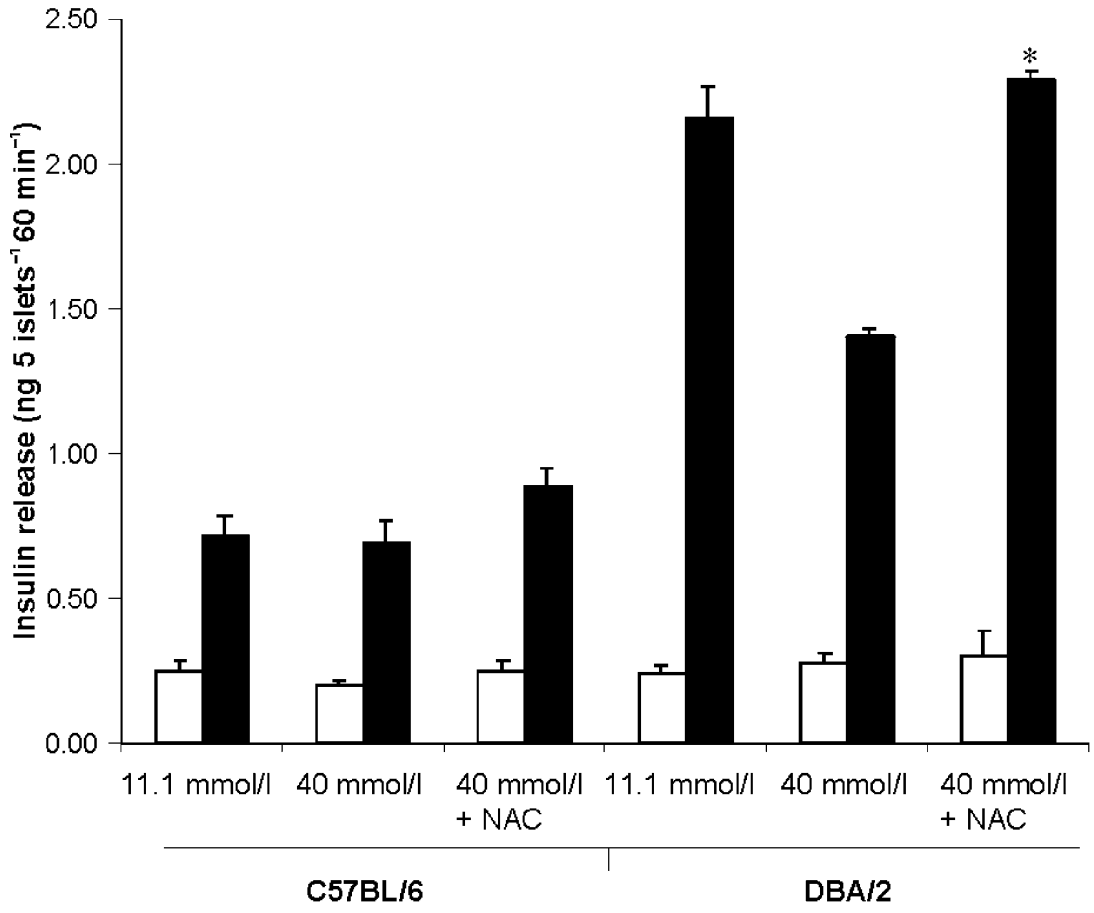


Fig. 6 mRNA levels of MnSOD (a), glutathione peroxidase (b), haeme oxygenase-1 (c), $\mathrm{Cu} /$ Zn-SOD (d), insulin (e) and catalase (f) as measured by realtime PCR. The value obtained for each specific product was expressed relative to the control gene for each sample (ratio of specific product: cyclophilin). These ratios were then expressed as a percentage of the ratio in C57BL/6 islet extracts. $* p<0.05$ vs $\mathrm{C} 57 \mathrm{BL} / 6$
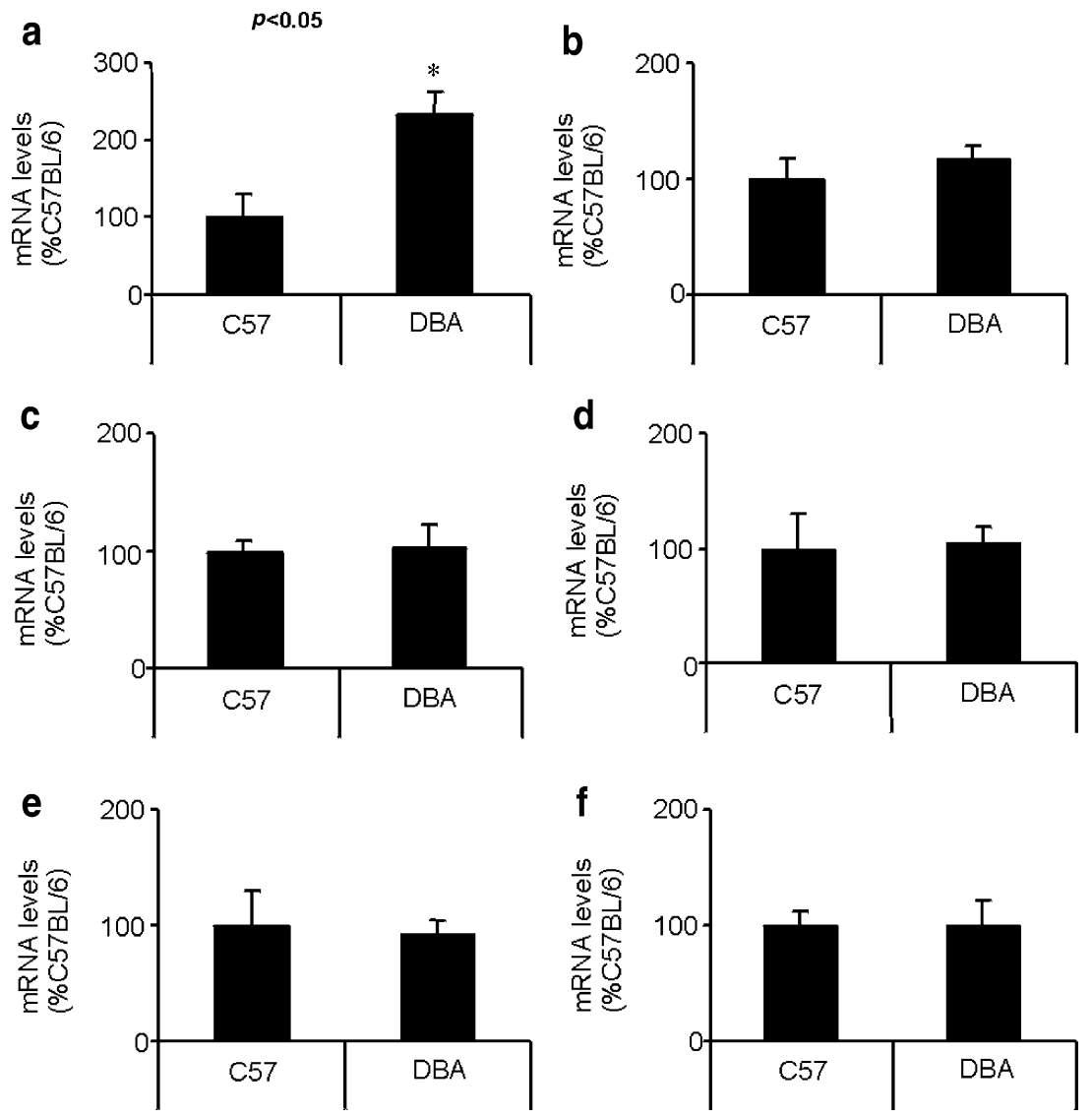

present study, we have compared insulin secretory function in the resilient $\mathrm{C} 57 \mathrm{BL} / 6$ strain with that in the susceptible $\mathrm{DBA} / 2$ strain following exposure to a high glucose environment and found that only DBA/2 islets display an impairment in GSIS. The data illustrate the influence of genetic background on the development of an insulin secretory defect. The increased levels of $\mathrm{H}_{2} \mathrm{O}_{2}$ in DBA/2 islets exposed to high glucose concentrations as well as the decreased ATP levels, suggest a role for oxidative stress in the impairment of GSIS.

The HBP has been described as a cellular sensor of energy availability $[34,35]$, capable of modifying many proteins via $O$-linked glycosylation $[36,37]$. We have recently shown that in the normal state, this pathway is involved in regulating the secretion of insulin by altering protein $O$-glycosylation [22]. Other studies have shown that accelerated flux through the HBP, as would be expected in type 2 diabetes, has resulted in beta cell dysfunction [38, 39]. Our present study showed that incubating islets with the HBP substrate glucosamine resulted in reduced GSIS not only in the susceptible DBA/2 mice but also in the C57BL/6 mouse islets. A possible explanation for this finding is that glucosamine is 40 times more potent than glucose in mediating its effects [40] and so an insulin secretion defect was seen in the C57BL/6 islets via mechanisms other than an increase in glycosylated proteins. It is noteworthy that neither $40 \mathrm{mmol} / 1$ glucose exposure nor NAC treatment had any effect on C57BL/6 islets, demonstrating that genetic susceptibility plays a significant part in the progression of beta cell dysfunction. This is supported by the inability of NAC to affect insulin secretion in non-diabetic C57BL/KsJ-misty/ misty mice but the ability normalise GSIS in C57BL/KsJ$d b / d b$ mice [41].

In the current study, we found that although $O$-glycosylation of islet proteins was elevated following high glucose exposure, it occurred in both strains of mice and, therefore, cannot explain the defect in GSIS from DBA/2 islets. This is supported by a study of rat islets overexpressing GFAT (the rate-limiting enzyme of the HBP), in which GSIS was impaired although not as a result of elevated $O$-glycosylation [21]. In this latter study, the HBP was implicated in oxidative stress-mediated beta cell dysfunction. Rat islets with adenovirus-mediated overexpression of GFAT combined with hyperglycaemia, revealed a reduction in GSIS that was partially restored by treatment with the antioxidant NAC [21]. Similarly, hyperglycaemia in beta cells has been shown to induce oxidative stress [18, $19,42]$ and antioxidant drugs have been shown to protect against this effect $[41,43,44]$. The data presented here agree with these studies, showing that $\mathrm{H}_{2} \mathrm{O}_{2}$ levels are increased in DBA/2 islets exposed to high glucose. Treatment with the antioxidant NAC prevented the rise in $\mathrm{H}_{2} \mathrm{O}_{2}$ levels while restoring GSIS and insulin content.

The cause of the increase in $\mathrm{H}_{2} \mathrm{O}_{2}$ levels when DBA/2 islets were exposed to $40 \mathrm{mmol} / \mathrm{l}$ glucose was probably an increase in levels of Mn-SOD, a mitochondrial enzyme which forms part of the cell's defence mechanism against 
a

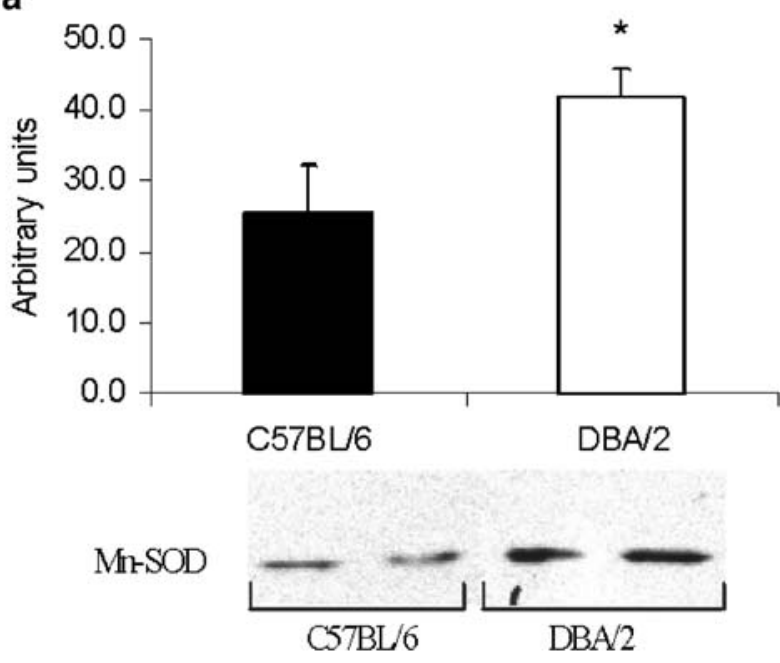

b

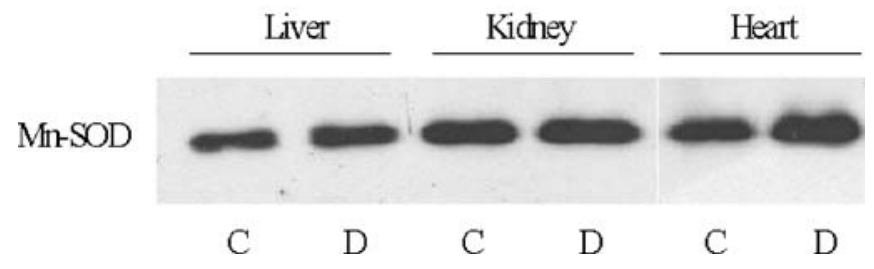

Fig. 7 a Mn-SOD protein levels in pancreatic mitochondrial lysates from DBA/2 and C57BL/6 mice. Values are presented as mean \pm SEM for three experiments. ${ }^{*} p<0.05$ vs $\mathrm{C} 57 \mathrm{BL} / 6$. b Mn-SOD protein levels in mitochondrial lysates from liver, kidney and heart tissue from DBA/2 (lanes $D$ ) and $\mathrm{C} 57 \mathrm{BL} / 6$ (lanes $C$ ) mice

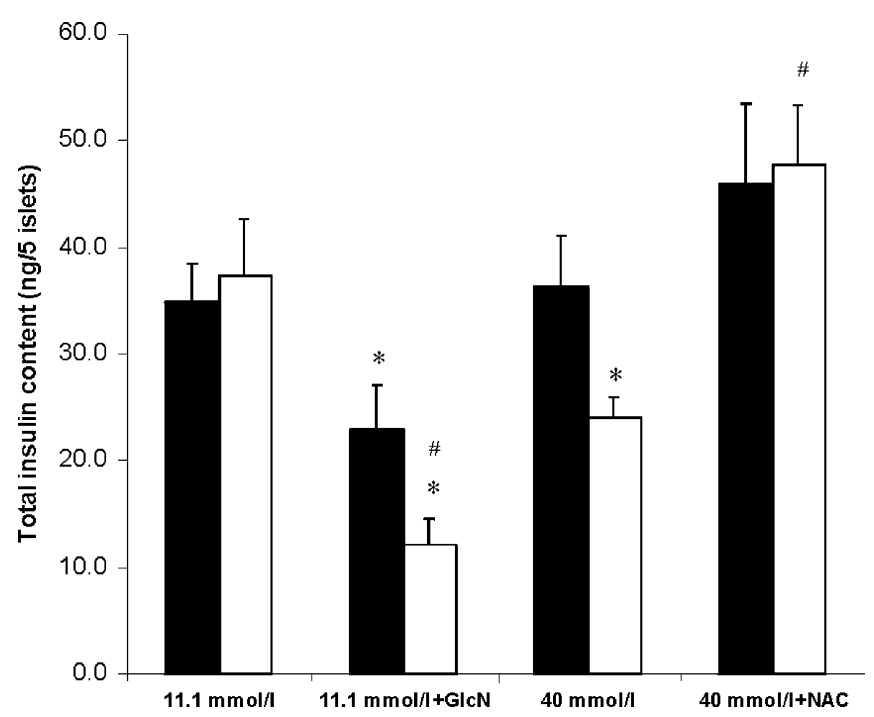

Fig. 8 Islet insulin content in C57BL/6 (closed bars) and DBA/2 (open bars) islets following $48 \mathrm{~h}$ incubation in either $11.1 \mathrm{mmol}$ with or without $3 \mathrm{mmol} / 1$ glucosamine $(G l c N)$ or $40 \mathrm{mmol} / 1$ glucose with or without $5 \mathrm{mmol} / 1 \mathrm{~N}$-acetyl-L-cysteine $(N A C)$. Values are presented as mean \pm SEM for four to six experiments. ${ }^{*} p<0.05$ vs $11.1 \mathrm{mmol} / \mathrm{l} ; \# p<0.05$ vs $40 \mathrm{mmol} / \mathrm{l}$

oxidative stress. Of interest is the finding that the cytosolic isoenzyme $\mathrm{Cu} / \mathrm{Zn}-\mathrm{SOD}$ was not increased in $\mathrm{DBA} / 2$ islets, suggesting that the deleterious effects of high glucose may largely affect mitochondrial function. The role of $\mathrm{Mn}-\mathrm{SOD}$ is to convert superoxide into $\mathrm{H}_{2} \mathrm{O}_{2}$ which is then converted to water and molecular oxygen by catalase. Thus the activity of both enzymes is required to safely remove superoxide. However, without a concomitant increase in catalase and glutathione peroxidase levels, an increase in $\mathrm{Mn}-\mathrm{SOD}$ causes an increase in $\mathrm{H}_{2} \mathrm{O}_{2}$ in DBA/2 islets exposed to high glucose concentrations and results in reduced GSIS. In support of this, it has been shown that upregulation of Mn-SOD alone does not protect beta cells from glycolysis-generated oxidative damage [45]. In fact, recent studies have shown that overexpression of Mn-SOD resulted in a higher rate of cell death, while catalase overexpression protected against cell death in response to mitochondrially generated superoxide radicals and a cytokine mixture containing IL- $1 \beta$, TNF- $\alpha$ and IFN $-\gamma$ in pancreatic (RINm5F) beta cells [46, 47]. Thus, our study and those referred to above support the concept that an increase in Mn-SOD, but not in catalase, will lead to an accumulation of hydrogen peroxide which is deleterious to cell function and viability [48]. It may, therefore, be necessary for a combination of antioxidant enzymes to be elevated for the protection of beta cells against oxidative stress $[47,49]$.

It has recently been suggested that a mechanism of hyperglycaemia-induced oxidative stress and consequent cell damage occurs via increased glycolysis and glucose oxidation $[20,50]$. It is of interest that we have previously shown that DBA/2 islets have increased glucokinase levels and subsequently higher islet glycolytic flux compared to C57BL/6 islets [30]. Furthermore, in the present study we show that two processes that are the result of glucose metabolism, islet ATP and glycosylated protein levels, are also elevated in DBA/2 islets. Thus our data also provide support for the hypothesis that an increase in glycolysis, which results in insulin hypersecretion, may also be responsible for the defects in insulin secretion in the diabetes-prone DBA/2 islets when there is excess substrate availability such as in hyperglycaemia. As a corollary, this hypothesis may also explain why the increased demand placed on the beta cell from insulin resistance or nutrient oversupply results in 'beta cell exhaustion' defects in insulin secretion in individuals with a predisposition to develop type 2 diabetes.

An interpretation of our findings is that the reduction in GSIS in DBA/2 islets following high glucose exposure reflects a return to 'normal' function from a hyperresponsive state. However, given that GSIS was increased back to the pre-glucose exposed state by treatment with an anti-oxidant, we believe that our interpretation of enhanced susceptibility of the DBA/2 islets to glucose toxicity is the more likely explanation of the data. It is difficult to see how oxidative damage could revert cell function to normal.

In conclusion, our data suggest that high glucose impairs GSIS in genetically susceptible islets and that this impairment may be the result of oxidative stress. A better understanding of the underlying genetic factors that contribute to these effects in the DBA/2 mouse may provide clues as to why some individuals develop type 2 
diabetes given the necessary environmental stimuli, while others do not.

Acknowledgements This work was supported by grants from the National Health and Medical Research Council of Australia (grant \# 114163 and 208945 to S. Andrikopoulos and J. Proietto) and a grantin-aid from the Diabetes Australia Research Trust Fund. We thank M. Ernst for his kind assistance in measuring islet ATP levels and J. McKie, P. Brazzoduro and C. Rantzau for technical assistance. S. Andrikopoulos was supported by an R. D. Wright Biomedical Career Development Award from the National Health and Medical Research Council of Australia.

\section{References}

1. Flatt P, Barnett C, Swanston-Flatt S (1994) Mechanisms of pancreatic B-cell dysfunction and glucose toxicity in noninsulin dependent diabetes. Biochem Soc Trans 22:18-23

2. Leahy J, Bonner-Weir S, Weir G (1992) Beta-cell dysfunction induced by chronic hyperglycaemia: current ideas on the mechanism of the impaired glucose-induced insulin secretion. Diabetes Care 15:442-455

3. Rossetti L, Giaccari A, DeFronzo RA (1990) Glucose toxicity. Diabetes Care 13:610-630

4. Sako Y, Grill V (1990) Coupling of beta-cell desensitization by hyperglycemia to excessive stimulation and circulating insulin in glucose-infused rats. Diabetes 39:1580-1583

5. Kaiser N, Corcos A, Sarel I, Cerasi E (1991) Monolayer culture of adult rat pancreatic islets on extracellular matrix: modulation of B-cell function by chronic exposure to high glucose. Endocrinology 129:2067-2076

6. Eizirik D, Korbutt S, Hellerstrom C (1992) Prolonged exposure of human islets to high glucose concentrations in vitro impairs the B-cell function. J Clin Invest 90:1263-1268

7. Poitout V, Olson LK, Robertson RP (1996) Chronic exposure of betaTC-6 cells to supraphysiologic concentrations of glucose decreases binding of the RIPE3b1 insulin gene transcription activator. J Clin Invest 97:1041-1046

8. Robertson R, Zhang H-J, Ryzdrowski K, Walseth T (1992) Preservation of insulin mRNA levels and insulin secretion in HIT cells by avoidance of chronic exposure to high glucose concentrations. J Clin Invest 90:320-325

9. Kajimoto Y, Matsuoka T, Kaneto H et al (1999) Induction of glycation suppresses glucokinase gene expression in HIT-T15 cells. Diabetologia 42:1417-1424

10. Kooptiwut S, Kebede M, Zraika S et al (2005) High glucoseinduced impairment in insulin secretion is associated with reduction in islet glucokinase in a mouse model of susceptibility to islet dysfunction. J Mol Endocrinol 35:39-48

11. Hribal ML, Perego L, Lovari S et al (2003) Chronic hyperglycemia impairs insulin secretion by affecting insulin receptor expression, splicing, and signaling in RIN beta cell line and human islets of Langerhans. Faseb J 17:1340-1342

12. Robertson RP, Harmon J, Tran PO, Tanaka Y, Takahashi H (2003) Glucose toxicity in beta-cells: type 2 diabetes, good radicals gone bad, and the glutathione connection. Diabetes 52:581-587

13. Lenzen S, Drinkgern J, Tiedge M (1996) Low antioxidant enzyme gene expression in pancreatic islets compared with various other mouse tissues. Free Radic Biol Med 20:463-466

14. Nishikawa T, Edelstein D, Du XL et al (2000) Normalizing mitochondrial superoxide production blocks three pathways of hyperglycaemic damage. Nature 404:787-790

15. Robertson RP, Harmon J, Tran PO, Poitout V (2004) Beta-cell glucose toxicity, lipotoxicity, and chronic oxidative stress in type 2 diabetes. Diabetes 53(Suppl 1):S119-S124

16. Del Guerra S, Lupi R, Marselli L et al (2005) Functional and molecular defects of pancreatic islets in human type 2 diabetes. Diabetes 54:727-735
17. Baynes JW (1991) Role of oxidative stress in development of complications in diabetes. Diabetes 40:405-412

18. Hunt JV, Dean RT, Wolff SP (1988) Hydroxyl radical production and autoxidative glycosylation. Glucose autoxidation as the cause of protein damage in the experimental glycation model of diabetes mellitus and ageing. Biochem J 256:205-212

19. Tanaka Y, Tran PO, Harmon J, Robertson RP (2002) A role for glutathione peroxidase in protecting pancreatic beta cells against oxidative stress in a model of glucose toxicity. Proc Natl Acad Sci USA 99:12363-12368

20. Wu L, Nicholson W, Knobel SM et al (2004) Oxidative stress is a mediator of glucose toxicity in insulin-secreting pancreatic islet cell lines. J Biol Chem 279:12126-12134

21. Kaneto H, Xu G, Song KH et al (2001) Activation of the hexosamine pathway leads to deterioration of pancreatic betacell function through the induction of oxidative stress. J Biol Chem 276:31099-31104

22. Zraika S, Dunlop M, Proietto J, Andrikopoulos S (2002) The hexosamine biosynthesis pathway regulates insulin secretion via protein glycosylation in mouse islets. Arch Biochem Biophys 405:275-279

23. Molina JM, Premdas FH, Klenck RE, Eddlestone G, Oldham SB, Lipson LG (1984) The dynamic insulin secretory response of isolated pancreatic islets of the diabetic mouse. Evidence for a gene dosage effect on insulin secretion. Diabetes 33: $1120-1123$

24. Leiter E, Coleman D, Hummel K (1981) The influence of genetic background on the expression of mutations at the diabetes locus in the mouse: effect of $\mathrm{H}-2$ haplotype and sex. Diabetes 30:1029-1034

25. Kooptiwut S, Zraika S, Thorburn AW et al (2002) Comparison of insulin secretory function in two mouse models with different susceptibility to beta-cell failure. Endocrinology 143:2085-2092

26. Gembal M, Detimary P, Gilon P, Gao Z-Y, Henquin J (1993) Mechanisms by which glucose can control insulin release independently from its action on adenosine triphosphate-sensitive $\mathrm{K}^{+}$ channels in mouse B-cells. J Clin Invest 91:871-880

27. Zraika S, Dunlop ME, Proietto J, Andrikopoulos S (2004) Elevated SNAP-25 is associated with fatty acid-induced impairment of mouse islet function. Biochem Biophys Res Commun 317:472-477

28. Chomczynski P, Sacchi N (1987) Single-step method of RNA isolation by acid guanidinium thiocyanate-phenol-chloroform extraction. Anal Biochem 162:156-159

29. Hodarnau A, Dancea S, Barzu O (1973) Isolation of highly purified mitochondria from rat pancreas. J Cell Biol 59: 222-227

30. Kooptiwut S, Zraika S, Thorburn AW et al (2002) Comparison of insulin secretory function in two mouse models with different susceptibility to beta-cell failure. Endocrinology 143:2085-2092

31. Konrad RJ, Tolar JF, Hale JE, Knierman MD, Becker GW, Kudlow JE (2001) Purification of the $O$-glycosylated protein p135 and identification as $O$-GlcNAc transferase. Biochem Biophys Res Commun 288:1136-1140

32. Pehuet-Figoni M, Ballot E, Bach JF, Chatenoud L (1994) Aberrant function and long-term survival of mouse beta cells exposed in vitro to high glucose concentrations. Cell Transplant $3: 445-451$

33. Gapp DA, Leiter EH, Coleman DL, Schwizer RW (1983) Temporal changes in pancreatic islet composition in C57BL/6J$d b / d b$ (diabetes) mice. Diabetologia 25:439-443

34. Rossetti L, Hawkins M, Chen W, Gindi J, Barzilai N (1995) In vivo glucosamine infusion induces insulin resistance in normoglycaemic but not in hyperglycaemic conscious rats. $\mathrm{J}$ Clin Invest 96:132-140

35. Hawkins M, Barzilai N, Hu M, Chen W, Rossetti L (1997) Role of glucosamine pathway in fat-induced insulin resistance. J Clin Invest 99:2173-2183 
36. Hanover JA (2001) Glycan-dependent signaling: $O$-linked $N$-acetylglucosamine. Faseb J 15:1865-1876

37. Hart GW (1997) Dynamic $O$-linked glycosylation of nuclear and cytoskeletal proteins. Annu Rev Biochem 66:315-335

38. Balkan B, Dunning BE (1994) Glucosamine inhibits glucokinase in vitro and produces a glucose-specific impairment of in vivo insulin secretion in rats. Diabetes 43:1173-1179

39. Tang J, Neidigh JL, Cooksey RC, McClain DA (2000) Transgenic mice with increased hexosamine flux specifically targeted to beta-cells exhibit hyperinsulinemia and peripheral insulin resistance. Diabetes 49:1492-1499

40. Marshall S, Bacote V, Traxinger R (1991) Discovery of a metabolic pathway mediating desensitization of the glucose transport system: role of hexosamine biosynthesis in the induction of insulin resistance. J Biol Chem 266:4706-4712

41. Kaneto H, Kajimoto Y, Miyagawa J et al (1999) Beneficial effects of antioxidants in diabetes: possible protection of pancreatic betacells against glucose toxicity. Diabetes 48:2398-2406

42. Ihara Y, Toyokuni S, Uchida K et al (1999) Hyperglycemia causes oxidative stress in pancreatic beta-cells of GK rats, a model of type 2 diabetes. Diabetes 48:927-932

43. Tiedge M, Lortz S, Munday R, Lenzen S (1999) Protection against the co-operative toxicity of nitric oxide and oxygen free radicals by overexpression of antioxidant enzymes in bioengineered insulin-producing RINm5F cells. Diabetologia 42: 849-855
44. Tanaka Y, Gleason CE, Tran PO, Harmon JS, Robertson RP (1999) Prevention of glucose toxicity in HIT-T15 cells and Zucker diabetic fatty rats by antioxidants. Proc Natl Acad Sci USA 96:10857-10862

45. Takahashi H, Tran PO, LeRoy E, Harmon JS, Tanaka Y, Robertson RP (2004) D-glyceraldehyde causes production of intracellular peroxide in pancreatic islets, oxidative stress, and defective beta cell function via non-mitochondrial pathways. J Biol Chem 279:37316-37323

46. Lortz S, Gurgul-Convey E, Lenzen S, Tiedge M (2005) Importance of mitochondrial superoxide dismutase expression in insulin-producing cells for the toxicity of reactive oxygen species and proinflammatory cytokines. Diabetologia 48: $1541-1548$

47. Gurgul E, Lortz S, Tiedge M, Jorns A, Lenzen S (2004) Mitochondrial catalase overexpression protects insulin-producing cells against toxicity of reactive oxygen species and proinflammatory cytokines. Diabetes 53:2271-2280

48. Gardner R, Salvador A, Moradas-Ferreira P (2002) Why does SOD overexpression sometimes enhance, sometimes decrease, hydrogen peroxide production? A minimalist explanation. Free Radic Biol Med 32:1351-1357

49. Lortz S, Tiedge M (2003) Sequential inactivation of reactive oxygen species by combined overexpression of SOD isoforms and catalase in insulin-producing cells. Free Radic Biol Med 34:683-688

50. Fridlyand LE, Philipson LH (2004) Does the glucose-dependent insulin secretion mechanism itself cause oxidative stress in pancreatic beta-cells? Diabetes 53:1942-1948 